\title{
Viral and intestinal diseases detected in Apis mellifera in Central and Southern Chile
}

Marisol Vargas ${ }^{1 *}$, Nolberto Arismendi ${ }^{1}$, Gustavo Riveros ${ }^{1}$, Nelson Zapata ${ }^{1}$, Alex Bruna ${ }^{1}$, Mayra Vidal ${ }^{1}$, Marta Rodríguez ${ }^{2}$, and Marcos Gerding ${ }^{2}$

\section{ABSTRACT}

The honeybee (Apis mellifera L.) is an important pollinator worldwide. Beekeepers have experienced an increasing loss of colonies in recent years and pathologies including viruses and intestinal parasites such as Nosema ceranae are among those held responsible for this decline. The aim of this study was to determine the prevalence and distribution, using the real time PCR method, of six honeybee viruses including Deformed Wing Virus (DWV), Black Queen Cell Virus (BQCV), Sacbrood Virus (SBV), Acute Bee Paralysis Virus (ABPV), Chronic Bee Paralysis Virus (CBPV) and Israeli Acute Paralysis Virus (IAPV) in addition to three intestinal parasites, $N$. ceranae, $N$. apis and Lotmaria passim in Chilean beehives distributed between the Metropolitan Region and La Araucanía Region. Among the viruses, BQCV was the most prevalent in the analyzed hives, ranging from $72 \%$ to $100 \%, N$. ceranae was detected between $19 \%$ to $53 \%$ and L. passim showed infections ranging from $45 \%$ to $73 \%$. Similarly, BQCV $(96 \%)$ and $N$. ceranae $(42 \%)$ were more prevalent in spring-summer whilst DWV $(37 \%)$ and L. passim $(68 \%)$ were more frequents in autumn-winter seasons. Furthermore, mixed infections were also detected, wherein viruses were found along with $L$. passim or viruses with $N$. ceranae and $L$. passim, which proved to be the most prevalent. Of the 467 hives analyzed, $97.2 \%$ were infected with one or more of the studied pathogens, indicating that they are widely spread in Chile.

Key words: Honeybee, honeybee viruses, Lotmaria passim, Nosema ceranae, PCR-real time detection.

${ }^{1}$ Universidad de Concepción, Facultad de Agronomía, Av. Vicente Méndez 595, Chillán, Chile.

*Corresponding author (marisolvargas@udec.cl).

${ }^{2}$ Centro de Producción de Insectos Benéficos BioBichos Ltda.,

Variante Cato s/n, Chillán, Chile.

Received: 10 March 2017.

Accepted: 5 July 2017.

doi:10.4067/S0718-58392017000300243

\section{INTRODUCTION}

The honeybee (Apis mellifera L.) is an important beneficial insect that assists in the pollination of many agricultural crops worldwide. In addition to providing pollination services, honeybees also produce honey, wax, and other diverse products (Delaplane and Mayer, 2004). Worldwide, beekeepers have experienced an increasing loss in colonies and several pathogens have been involved in these colonies' decline, among them viruses (Evans and Schwarz, 2011). About 24 viruses have been identified worldwide (de Miranda et al., 2013); among these viruses the most commonly observed and best known are Deformed Wing Virus (DWV), Black Queen Cell Virus (BQCV), Sacbrood Virus (SBV), Acute Bee Paralysis Virus (ABPV), Chronic Bee Paralysis Virus (CBPV) and Israeli Acute Paralysis Virus (IAPV), which have been described in detail by Kukielka and Sanchez-Vizcaino (2009). Although some of these viruses produce recognizable symptoms at sufficiently elevated titers, they generally persist naturally in honeybee populations at low levels (de Miranda et al., 2013). These viruses are transmitted horizontally from bee to bee, or vertically since viruses infect ovarian tissues of the queen and disseminate in developing eggs before oviposition (Chen et al., 2006). On the other hand, two microsporidian species have proven to infect honeybees worldwide: Nosema apis Zander and N. ceranae Fries (Higes et al., 2006). Both are obligate intracellular gut parasites, which cause a disease known as nosemosis. Nosema ceranae and $N$. apis play an important role in the epidemiology of honeybee microsporidiosis worldwide because these pathogens negatively affect productivity and survival of honeybee colonies (Botías et al., 2013). However, in the last decade in many places of the world N. apis has been displaced by N. ceranae (Fries, 2010); which has been involved in honeybee colony collapse disorder (Higes et al., 2008). Similarly, a new intestinal pathogen called Lotmaria passim Evans and Schwarz has recently been detected in honeybees (Schwarz et al., 2015). Nowadays, L. passim appears to be the predominant trypanosome in honeybees worldwide (Schwarz et al., 2015; Arismendi et al., 2016). Trypanosomatids are unicellular flagellates and obligate parasites that infect different groups of hosts including mammals, plants and insects (Maslov et al., 2013).

Beekeeping is an important activity in Chile; pollination services for fruit and seed production is estimated at US\$15 million, and exports in honeybee products, mainly honey, bring in around US\$27 million per year (Valdés, 2014). Chilean apiaries 
are concentrated mainly in the central and south-central region of the country, with $75 \%$ of beekeeping operations located between the Metropolitan and La Araucanía Regions (Velis et al., 2009). Although there is no official information about the mortality of colonies in Chile, beekeepers have observed an increase in the loss of colonies in recent years. The causes are still unclear. Studies on the impact of pathogens on honeybee colonies need data concerning the prevalence of these diverse pathogens. Therefore, in this research we evaluated the prevalence and distribution of six viruses, including Deformed Wing Virus (DWV), Black Queen Cell Virus (BQCV), Sacbrood Virus (SBV), Acute Bee Paralysis Virus (ABPV), Chronic Bee Paralysis Virus (CBPV), Israeli Acute Paralysis Virus (IAPV) and three intestinal parasites Nosema ceranae, Nosema apis and Lotmaria passim in beehives located in the main Chilean apiculture regions.

\section{MATERIALS AND METHODS}

\section{Field sampling, nucleic acid isolation and cDNA synthesis}

A group of 50 worker bees were collected from spring 2014 to fall 2015 from 467 beehives distributed in the Metropolitan (3326' S, 70³9' W), Libertador General Bernardo O'Higgins ( $\left.34^{\circ} 10^{\prime} \mathrm{S}, 70^{\circ} 43^{\prime} \mathrm{W}\right)$, Maule $\left(35^{\circ} 25^{\prime}\right.$

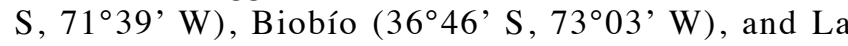
Araucanía (38 $44^{\prime} \mathrm{S}, 72^{\circ} 35^{\prime} \mathrm{W}$ ) Regions. Ten honeybees were crushed and homogenized in a stomacher bag with $10 \mathrm{~mL}$ phosphate-buffered saline (PBS 1X) for $90 \mathrm{~s}$ at high speed in a Stomacher 80 Lab Blender (Seward, London, $\mathrm{UK})$. These samples were centrifuged twice at $1500 \mathrm{~g}$ for $10 \mathrm{~min}$, followed by $10.000 \mathrm{~g}$ for $10 \mathrm{~min}$, both at $4{ }^{\circ} \mathrm{C}$. Then, $200 \mu \mathrm{L}$ supernatant were used for RNA isolation according to instructions provided by the E.Z.N.A. Total
RNA Kit I (Omega Bio-Tek, Norcross, Georgia, USA). For DNA extraction, $200 \mu \mathrm{L}$ pellet was ground in $1.5 \mathrm{~mL}$ microcentrifuge tubes using sterile plastic pestles with 350 $\mu \mathrm{L}$ CTL buffer following the E.Z.N.A Insect DNA Kit's instructions (Omega, Bio-Tek). The DNA and RNA was quantified (Infinite 200 PRO NanoQuant, Tecan Group, Männedorf, Switzerland) and stored at $-80^{\circ} \mathrm{C}$.

The RNA was used for first-strand cDNA synthesis, which was performed using the M-MLV reverse transcriptase enzyme (Invitrogen, Life Technologies, Carlsbad, California, USA), according to the manufacturer's recommendations. The cDNA samples were maintained at $-20{ }^{\circ} \mathrm{C}$ until the virus analysis was carried out.

\section{Real-time PCR for pathogen detection}

In order to detect the prevalence of BQCV, DWV, IAPV, SBV, ABPV, CBPV, N. ceranae, N. apis and L. passim in Chilean honeybee apiaries, real-time PCR was conducted with specific primers (Table 1). The PCR reactions were carried out in $15 \mu \mathrm{L}$, containing $20 \mathrm{ng}$ of DNA, or cDNA for virus analysis, 1X of KAPA SYBR FAST Universal 2X qPCR Master Mix (Kapa Biosystems, Wilmington, Massachusetts, USA), $530 \mathrm{nM}$ of each primer, and filled with sterile-filtered molecular grade water. The thermal conditions were achieved with one cycle at $96{ }^{\circ} \mathrm{C}$ for 10 min, followed by 40 cycles at $95{ }^{\circ} \mathrm{C}$ for $15 \mathrm{~s}, 60^{\circ} \mathrm{C}$ for 15 $\mathrm{s}$ and $72{ }^{\circ} \mathrm{C}$ for $30 \mathrm{~s}$. A dissociation analysis was conducted after all of the amplifications were completed in order to detect the primer dimmers and the unspecific amplicons. Primers designed by Yang and Cox-Foster (2005) based on the $\beta$-actin gene were used as an internal control (Table 1). Real time PCR assays were performed in a thermocycler Stratagene Mx3000P (Agilent Technologies, Santa Clara, California, USA), and the data were analyzed using MxPro software (Stratagene). The data are shown as percentages

Table 1. Primers used for the detection of honeybee pathogens in real time PCR.

\begin{tabular}{|c|c|c|c|c|}
\hline Pathogen & & Primers $5^{\prime} \rightarrow 3^{\prime}$ & Target sequence & Reference \\
\hline $\mathrm{BQCV}$ & $\begin{array}{l}\mathrm{F} \\
\mathrm{R}\end{array}$ & $\begin{array}{l}\text { AAGGGTGTGGATTTCGTCAG } \\
\text { GGCGTACCGATAAAGATGGA }\end{array}$ & Capsid protein & Kukielka et al., 2008 \\
\hline DWV & $\begin{array}{l}\mathrm{F} \\
\mathrm{R}\end{array}$ & $\begin{array}{l}\text { CTGTATGTGGTGTGCCTGGT } \\
\text { TTCAAACAATCCGTGAATATAGTGT }\end{array}$ & Polyprotein gene & Kukielka et al., 2008 \\
\hline IAPV & $\begin{array}{l}\mathrm{F} \\
\mathrm{R}\end{array}$ & $\begin{array}{l}\text { CCATGCCTGGCGATTCAC } \\
\text { CATCCATGTTCCTAGCCGATGA }\end{array}$ & Capsid protein & De Miranda et al., 2010 and this study \\
\hline SBV & $\begin{array}{l}\mathrm{F} \\
\mathrm{R}\end{array}$ & $\begin{array}{l}\text { GGGTCGAGTGGTACTGGAAA } \\
\text { ACACAACACTCGTGGGTGAC }\end{array}$ & Polyprotein gene & Johnson et al., 2009 \\
\hline ABPV & $\begin{array}{l}\mathrm{F} \\
\mathrm{R}\end{array}$ & $\begin{array}{l}\text { GGTGCCCTATTTAGGGTGAGGA } \\
\text { ACTACAGAAGGCAATGTCCAAGA }\end{array}$ & Capsid protein & Sguazza et al., 2013 \\
\hline CBPV & $\begin{array}{l}\mathrm{F} \\
\mathrm{R}\end{array}$ & $\begin{array}{l}\text { TCAGACACCGAATCTGATTATTG } \\
\text { ACTACTAGAAACTCGTCGCTTCG }\end{array}$ & RNA-dependent RNA polymerase & Blanchard et al., 2009 \\
\hline Nosema ceranae & $\begin{array}{l}\mathrm{F} \\
\mathrm{R}\end{array}$ & $\begin{array}{l}\text { GAGAGAACGGTTTTTTGTTTGAGA } \\
\text { ATCCTTTCCTTCCTACACTGATTG }\end{array}$ & Ribosomal RNA gene & Huang and Solter, 2013 \\
\hline N. apis & $\begin{array}{l}\mathrm{F} \\
\mathrm{R}\end{array}$ & $\begin{array}{l}\text { CGTACTATGTACTGAAAGATGGACTGC } \\
\text { AGGTCTCACTCTTACTGTACATATGTTAGC }\end{array}$ & Ribosomal RNA gene & Huang and Solter, 2013 \\
\hline Lotmaria passim & $\begin{array}{l}\mathrm{F} \\
\mathrm{R}\end{array}$ & $\begin{array}{l}\text { AGGGATATTTAAACCCATCGAA } \\
\text { ACCACAAGAGTACGGAATGC }\end{array}$ & Ribosomal RNA gene & Arismendi et al., 2016 and this study \\
\hline$\beta$-Actin & $\begin{array}{l}\mathrm{F} \\
\mathrm{R}\end{array}$ & $\begin{array}{l}\text { ATGCCAACACTGTCCTTTCTGG } \\
\text { GACCCACCAATCCATACGGA }\end{array}$ & $\beta$-actin gene & Yang and Cox-Foster, 2005 \\
\hline
\end{tabular}


of prevalence based on positive cases regarding the total number of cases (467 honeybee hives). Total prevalence was analyzed by chi-square test $\left(\mathrm{X}^{2}\right)(\mathrm{p}<0.05)$. The prevalence of honeybee pathogens in each region (spatial analysis), and in warm (spring/summer) and cold (autumn/ winter) conditions (temporal analysis) we also analyzed by chi-square test using STATISTICA 7.0 software (StatSoft, Tulsa, OK, USA).

\section{RESULTS AND DISCUSSION}

In a 1-yr survey (autumn 2014 to summer 2015) in apiaries distributed throughout Chile and using real-time PCR with specific primers, we were able to detect that $97.2 \%$ (454/467) of the evaluated honeybee hives were infected with one or more of the pathogens under study. However, the microsporidium $N$. apis was not detected in any of the honeybee samples. Among the pathogens detected, the most prevalent were the viruses $(420 / 467)$ and were significant higher than L. passim $\left(290 / 467 ; \mathrm{X}^{2}=99.25, p\right.$ $<0.001, \mathrm{df}=1)$ and N. ceranae $\left(154 / 467 ; \mathrm{X}^{2}=319.81\right.$, $p<0.001, \mathrm{df}=1)$ Similarly, the prevalence between $L$. passim and $N$. ceranae was also significantly different $\left(\mathrm{X}^{2}=79.40, p<0.001, \mathrm{df}=1\right)$ (Figure 1).

The viruses BQCV, DWV, CBPV, ABPV and the parasites $N$. ceranae and $L$. passim were detected in honeybee samples from apiaries found in all of the analyzed regions and some cases, the prevalence varied significantly between these regions (Figure 2, Table 2). IAPV and SBV were not detected in any of the analyzed samples. Among the viruses analyzed, BQCV and DWV were the most prevalent (Figure 2). BQCV prevalence ranged from $72 \%$ (Maule Region) to 100\% (Metropolitan Region)
(Figure 2). However, the prevalence was nonsignificant different in nearby localities such as Metropolitan and O'Higgins or Maule and Biobío Regions (Table 2). The statistical difference in BQCV was only detected when the comparison was done from central to southern regions (Table 2). Similarly, the DWV prevalence was significant higher in La Araucanía (46\%) when the comparison was done with Biobío Region (8\%) (Table 2). Although the DWV prevalence in the other regions was low compared to La Araucanía Region, these cases were not significantly different (Figure 2, Table 2). In fact, BQCV and DWV are the two most common and prevalent virus infections in

Figure 1. Total prevalence of viruses, Nosema ceranae and Lotmaria passim in Chilean honeybee hives.

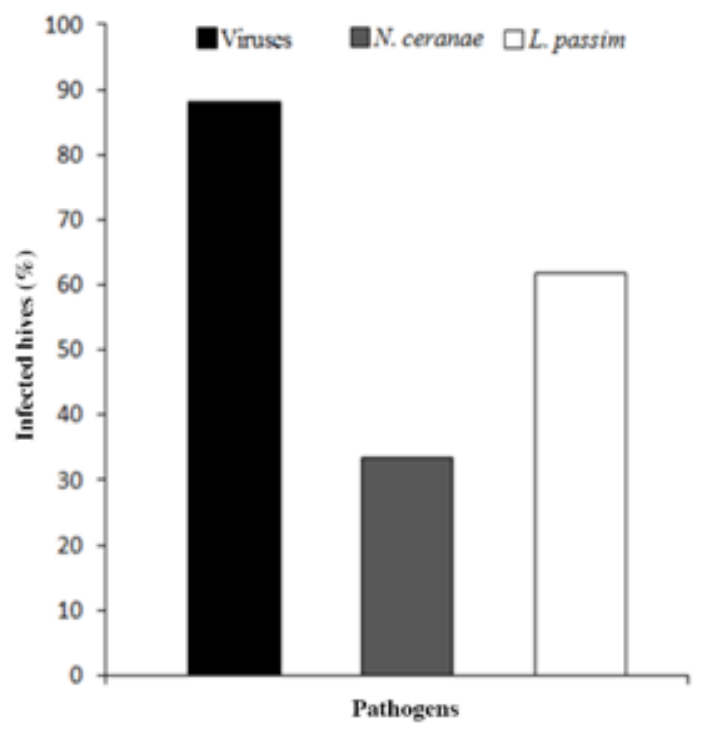

Figure 2. Prevalence of viruses and intestinal pathogens in honeybee hives in the principal apicultural regions in Chile.

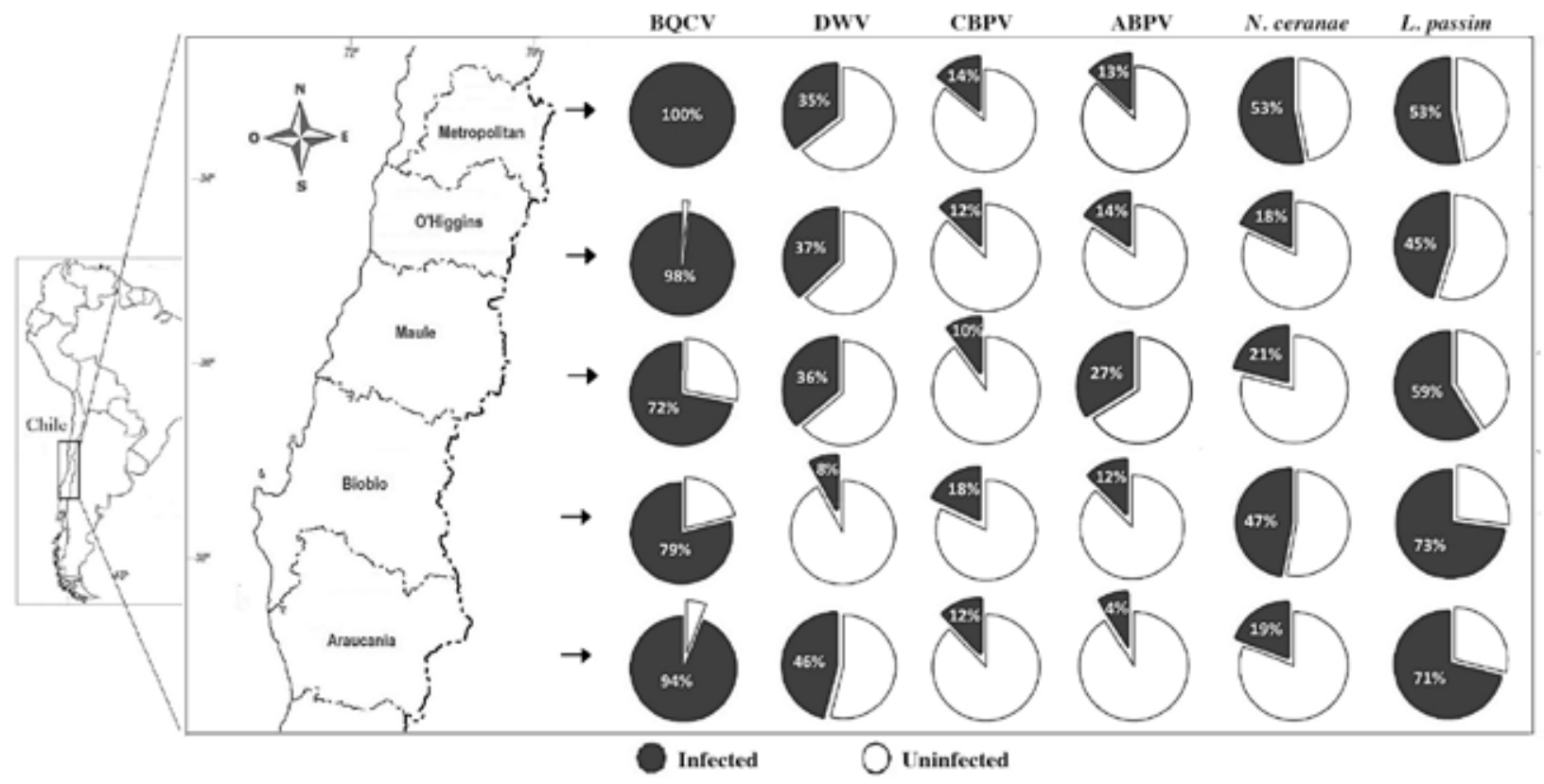

BQCV: Black Queen Cell Virus; DWV: Deformed Wing Virus; CBPV: Chronic Bee Paralysis Virus; ABPV: Acute Bee Paralysis Virus; Nosema ceranae; Lotmaria passim. 
A. mellifera worldwide (Zhang et al., 2012). In addition, DWV has been associated with honeybee colony losses, especially in overwintering mortalities in some places in the world (Highfield et al., 2009; McMenamin and Genersch, 2015) and DWV is known to be a lethal pathogen for honeybees when it occurs at high loads in association with the ectoparasite Varroa destructor (Dainat et al., 2012). BQCV mainly affects developing queen larvae and pupae in the capped-cell stage causing the death of future queen bees (Chen and Siede, 2007; McMenamin and Genersch, 2015). There is no clear evidence of the harmful effects of BQCV alone in adult honeybees; however, the synergistic interaction between $N$. ceranae and BQCV increases the mortality under controlled conditions (Doublet et al., 2015).

Nosema ceranae was detected in all the regions. However, honey bees collected from hives in the Metropolitan and Biobío Regions were the most infected (53\% and $47 \%$, respectively) and were significantly higher than those in the O'Higgins, Maule, and La Araucanía Regions (Figure 2, Table 2). Although some studies have shown that the geographic distribution of $N$. apis and $N$. ceranae may overlap and co-infections may occur (Gisder et al., 2010), in the present study only $N$. ceranae was detected in honeybee hives. On a global scale, the first report of $N$. ceranae infecting A. mellifera was in 2005 (Higes et al., 2006), but it has in fact been shown that honeybee hives were infected with this intestinal parasite long before this first report (Chen et al., 2008). In Chile, $N$. ceranae was detected for the first time in honeybees in 2009 (SAG, 2010); prior to this $N$. apis was the only causal agent of nosemosis in Chilean honeybees (Hinojosa and González, 2004). On the contrary, the present study has shown that $N$. ceranae is widely distributed throughout Chile (Figure 2), which could suggest that $N$. ceranae has displaced $N$. apis in Chilean apiaries as it has in several populations across Europe (Klee et al., 2007). However, other studies have found no evidence that this replacement is occurring worldwide (Paxton et al., 2007; Gisder et al., 2010; Martín-Hernández et al., 2012). In fact, experimental evidence has shown that mixed infections of $N$. ceranae and $N$. apis had higher spore numbers than bees with single infections, showing that there were not detected a competitive advantage for $N$. ceranae in mixed infections. Therefore, $N$. ceranae does not appear to have a strong within-host advantage for either infectivity or spore growth, suggesting that direct competition in worker bee mid-guts is not responsible for its apparent replacement of $N$. apis (Milbrath et al., 2015). In another recent report in Chile, $N$. apis has been detected to have a low prevalence $(3 \%)$ by molecular tools (Rodríguez et al., 2014) and in some cases, $N$. apis has not been detected at all (Bravo et al., 2014). Considering that the use of molecular tools for identifying Nosema species is relatively recent, previous reports of $N$. apis infections, prior to 2009 in Chile, were carried out with light microscopy only; therefore, there is a possibility that morphological identifications mistakenly identified $N$. ceranae as $N$. apis. However, we have no honeybee samples before the SAG report (SAG, 2010) and hence, cannot test this hypothesis. Studies of detections of $N$. ceranae and $N$. apis in old-conserved honey samples in South America, with the help of molecular tools, have concluded that $N$. ceranae has been present in the subcontinent since before the 90s (Invernizzi et al., 2009; Teixeira et al., 2013), indicating that $N$. ceranae has infected the European and Africanized honeybees in South America before it was first reported in Europe (Higes et al., 2006).

The prevalence of Lotmaria passim was higher Biobío Region (73\%), but nonsignificantly different from sample collected in La Araucanía Region (71\%) (Figure 2, Table $2)$. The lowest percentage L. passim infection in honey bee colonies was detected in the O'Higgins Region (45\%), showing nonsignificant differences from Maule Region (Figure 2, Table 2). Although L. passim has recently been described as a new species infecting honeybees (Schwarz et al., 2015), this species is currently the most predominant trypanosomatid in honeybees worldwide. This is due to the fact that many isolates initially identified as Crithidia mellificae Langridge and McGhee 1967 were reclassified as L. passim (Schwarz et al., 2015). Trypanosomes found in pollinators, especially honey and bumblebees have become more relevant in recent years since they have shown to have negative effects on behavior, physiology, fitness and the immune system (Ravoet et al., 2013; Schwarz and Evans, 2013). Although the role that L. passim plays in

Table 2. Spatial comparison by chi-square test of the honey bee pathogens detected in different regions of Chile.

\begin{tabular}{|c|c|c|c|c|c|c|c|c|c|c|c|c|}
\hline \multirow[b]{2}{*}{ Comparison } & \multicolumn{2}{|c|}{ BQCV } & \multicolumn{2}{|c|}{ DWV } & \multicolumn{2}{|c|}{ CBPV } & \multicolumn{2}{|c|}{ ABPV } & \multicolumn{2}{|c|}{ Nosema ceranae } & \multicolumn{2}{|c|}{ Lotmaria passim } \\
\hline & $\mathrm{X}^{2}$ & $p$-value & $\mathrm{X}^{2}$ & $p$-value & $\mathrm{X}^{2}$ & $p$-value & $\mathrm{X}^{2}$ & $p$-value & $\mathrm{X}^{2}$ & $p$-value & $\mathrm{X}^{2}$ & $p$-value \\
\hline MR vs. VI & 2.28 & 0.130 & 0.07 & 0.791 & 0.16 & 0.689 & 0.09 & 0.764 & 22.37 & $<0.001$ & 1.21 & 0.271 \\
\hline MR vs. VII & 28.61 & $<0.001$ & 0.01 & 0.920 & 0.45 & 0.502 & 5.53 & 0.019 & 19.00 & $<0.001$ & 0.52 & 0.471 \\
\hline MR vs. VIII & 21.21 & $<0.001$ & 25.00 & $<0.001$ & 0.75 & 0.386 & 0.01 & 0.920 & 0.77 & 0.380 & 8.89 & 0.003 \\
\hline MR vs. IX & 5.03 & 0.025 & 1.97 & 0.160 & 0.08 & 0.777 & 3.74 & 0.053 & 23.00 & $<0.001$ & 5.94 & 0.015 \\
\hline VI vs. VII & 19.70 & $<0.001$ & 0.03 & 0.862 & 0.07 & 0.791 & 3.93 & 0.047 & 0.17 & 0.680 & 3.11 & 0.078 \\
\hline VI vs. VIII & 13.78 & $<0.001$ & 26.74 & $<0.001$ & 1.58 & 0.209 & 0.19 & 0.662 & 18.36 & $<0.001$ & 16.53 & $<0.001$ \\
\hline VI vs. IX & 0.94 & 0.332 & 1.21 & 0.271 & 0.02 & 0.889 & 4.79 & 0.286 & 0.02 & 0.887 & 11.89 & $<0.001$ \\
\hline VII vs. VIII & 1.39 & 0.238 & 24.91 & $<0.001$ & 2.32 & 0.128 & 7.54 & 0.006 & 15.14 & $<0.001$ & 4.39 & 0.036 \\
\hline VII vs. IX & 15.89 & $<0.001$ & 1.61 & 0.204 & 0.16 & 0.689 & 16.67 & $<0.001$ & 0.07 & 0.791 & 2.72 & 0.099 \\
\hline VIII vs. IX & 10.22 & 0.001 & 41.73 & $<0.001$ & 1.38 & 0.240 & 3.78 & 0.052 & 18.93 & $<0.001$ & 0.09 & 0.764 \\
\hline
\end{tabular}

$\mathrm{X}^{2}$ : Chi-square test; df: 1.

BQCV: Black Queen Cell Virus; DWV: Deformed Wing Virus; CBPV: Chronic Bee Paralysis Virus; ABPV: Acute Bee Paralysis Virus.

MR: Metropolitan Region, VI: Libertador General Bernardo O’Higgins Region, VII: Maule Region, VIII: Biobío Region, IX: La Araucanía Region. 
honeybee diseases is still under discussion, it is evident that new stresses caused by this pathogen could influence the dynamics of honeybee health (Arismendi et al., 2016).

A temporal difference was also detected in the honeybee pathogens. These results showed that the viruses occur persistently in honeybee hives in spatial and temporal distribution. DWV was detected more frequent and significantly $\left(\mathrm{X}^{2}=6.26, p=0.012, \mathrm{df}=1\right)$ in cold $(84 / 224)$ than warm (63/240) conditions (Figure 3). The data have some logic since the DWV is quite prevalent when varroa mites are present in the hive (Dainat et al., 2012). In Chile, the highest prevalence of varroa mites occurs between late summer to early autumn. In this period, beekeepers normally realize varroa control. However, we have observed that the high prevalence of DWV can continue up to 2-mo after that control was done (data no shown). Contrary, the BQCV prevalence was higher in warm (231/240) than cold (114/227) condition (Figure 3$)$, and the virus level was significantly different between these periods $\left(\mathrm{X}^{2}=128.07, p<0.001, \mathrm{df}=1\right)$. BQCV is quite common in spring-summer seasons (Chen and Siede, 2007), since in this period the colonies are increasing their population and new queens and swarms are frequently generated; then, our data of prevalence are related to this BQCV behavior.

Both ABPV and CBPV showed prevalence slightly higher in cold $(\mathrm{ABPV}=84 / 227$; $\mathrm{CBPV}=84 / 227)$ than warm $(\mathrm{ABPV}=26 / 240 ; \mathrm{CBPV}=38 / 240)$, but this prevalence was nonsignificant different in both conditions $\left(\mathrm{ABPV} \mathrm{X} \mathrm{X}^{2}=2.99, p=0.084\right.$; CBPV X ${ }^{2}=0.89, p=0.345$, $\mathrm{df}=1)$. The sporadic detection of both viruses during the sampling times, suggest that these pathogens are less frequent than BQCV and DWV (Figure 2). This information also suggests the outbreaks cases of both ABPV and CBPV in Chile are not influenced by season, but rather, by other factors no determinate in this study.

Nosema ceranae prevalence was significantly higher $\left(\mathrm{X}^{2}=16.72, p<0.001, \mathrm{df}=1\right)$ in warm $(101 / 240)$ than cold (55/227) condition. Nosema ceranae abundance generally peaked spring and summer due to beekeepers try not to do a control in this period since that antifungal (Fumagilin-B) may remain in the colony and contaminate the honey. Then, late summer the hives are regularly treated with Fumagelin-B, reducing the $N$. ceranae levels in cold condition, but also this difference may represent natural seasonal variation (Runckel et al., 2011). On the other hand, L. passim infection was statistically higher in cold (154/227) than warm $(139 / 240)$ conditions $\left(\mathrm{X}^{2}=4.92, p=0.027\right.$, df =1) (Figure 3). The seasonal variation of trypanosome detected in Chile is not different to other reports in other countries; in fact, trypanosome such as $C$. mellificae has a similar level when it was sampled in autumn-winter seasons (Runckel et al., 2011). However, we have not enough information about the seasonal variation since this honeybee pathogen have been recently described and reported in Chile and the world (Schwarz et al., 2015; Arismendi et al., 2016).

Mixed infections were detected in honeybee samples, but these simultaneous pathogen infections varied according to the co-infection relationship detected (Figure 4$)$. The greatest number of cases (148/467) of coinfection proved to be viruses with $L$. passim, followed by tripartite mixed infections of viruses, N. ceranae and L. passim (105/467). There is no current evidence regarding the effect these kinds of coinfections could have on the health of honeybees or other pollinators, such as Bombus spp. Therefore, new research is required since the prevalence of these coinfections were higher than other coinfections (Figure 4). In fact, mixed infections of $N$. ceranae and viruses were

Figure 4. Mixed infections detected in Chilean honeybee hives.

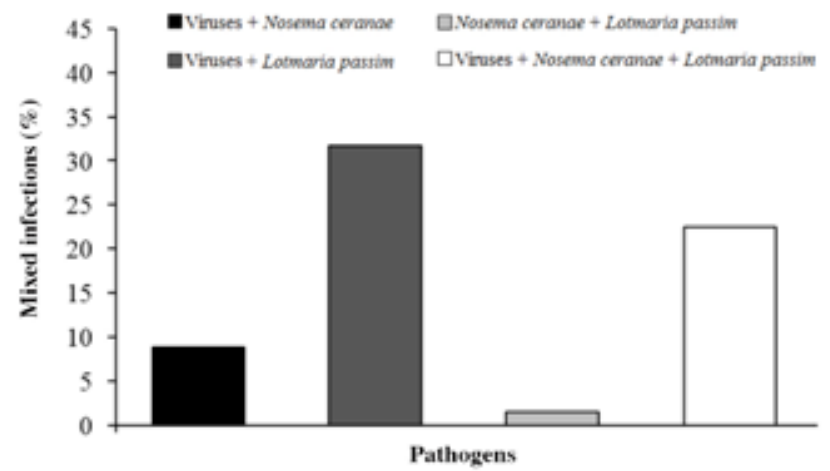

Figure 3. Temporal distribution of pathogens detected in Chilean honeybee hives.

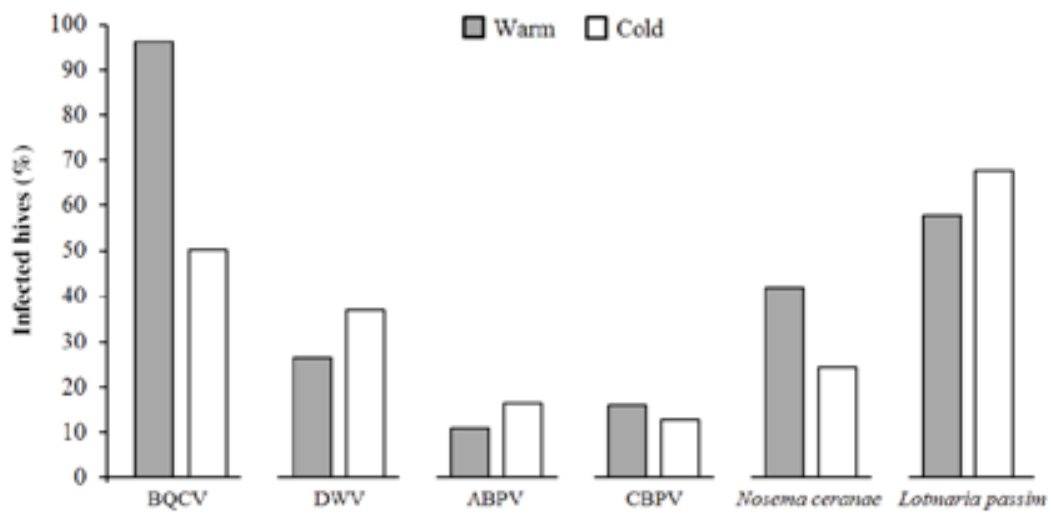

BQCV: Black Queen Cell Virus; DWV: Deformed Wing Virus; ABPV: Acute Bee Paralysis Virus; CBPV: Chronic Bee Paralysis Virus. 
only found in approximately $9 \%$ of the evaluated beehives (41/467) (Figure 4). However, a synergistic effect between $N$. ceranae and viruses is highly plausible since honeybee viruses have often been reported simultaneously in the same host (Runckel et al., 2011). There are e.g. synergic effects between $N$. ceranae and DWV on honeybee health, which is dependent, in some cases, on pathogen titers and pollen nutrition (Zheng et al., 2015). Similarly, there were only seven cases (7/467) of mixed infections of $N$. ceranae and L. passim (Figure 4). No evidence has yet been reported regarding the synergic effects of these two intestinal pathogens on honeybees. Furthermore, no research has yet reported a phenomenon of competence or displacement between Nosema spp. and L. passim, which could influence the virulence and pathogen distribution in the host. Consequently, new studies are required.

Previous studies have demonstrated the presence of viruses, N. ceranae and L. passim in specific regions of Chile and with a limited number of samples (Rodríguez et al., 2014; Bravo et al., 2014; Arismendi et al., 2016), but no country-level study has previously been carried out including the main apicultural regions of Chile. The results of this study demonstrate that only $2.8 \%$ of the samples evaluated were uninfected, indicating that mostly honeybee hives are infected and/or co-infected with one or more pathogens. These results have great relevance for honeybee health and show that these pathogens are widely spread throughout Chile.

The health status of beehives is a global concern (Evans and Schwarz, 2011; Maggi et al., 2016). This study contributes substantially to our limited knowledge about the health status of Chilean beehives in relation to the studied pathologies.

\section{CONCLUSION}

The current study detected that honeybee hives distributed between La Araucanía and Metropolitan Regions were infected with one or more pathogens under study. Among these pathogens, the most prevalent were the viruses BQCV, DWV, CBPV and ABPV, followed by the parasites Lotmaria passim and Nosema ceranae. The viruses IAPV, SBV and the microsporidium $N$. apis were not detected. There were also detected a temporal difference in the honeybee pathogens wherein the BQCV and $N$. ceranae were more prevalent in spring-summer whilst DWV and L. passim was more frequents in autumn-winter season. Mixed infections were also detected in honeybee samples; thus, the greatest number of cases the coinfection consisted of viruses along with $L$. passim, followed by tripartite mixed infection of viruses, $N$. ceranae and L. passim. This study demonstrated that most of the samples evaluated were affected by viruses, microsporidian or trypanosomes, indicating that honeybee hives throughout Chile are infected and co-infected with one or more pathogens of global relevance.

\section{ACKNOWLEDGEMENTS}

This study was supported by Grants FONDECYT N ${ }^{\circ}$ 1140653 , FONDECYT $\mathrm{N}^{\circ} 3150231$ and FONDECYT $\mathrm{N}^{\circ}$ 1171781 from the National Commission for Scientific and Technological Research, CONICYT, Chile.

\section{REFERENCES}

Arismendi, N., Bruna, A., Zapata, N., and Vargas, M. 2016. PCR-specific detection of recently described Lotmaria passim (Trypanosomatidae) in Chilean apiaries. Journal of Invertebrate Pathology 134:1-5.

Blanchard, P., Schurr, F., Olivier, V., Celle, O., Antúnez, K., Bakonyi, T., et al. 2009. Phylogenetic analysis of the RNA-dependant RNA polymerase (RdRp) and a predicted structural protein ( $\mathrm{pSP}$ ) of the Chronic bee paralysis virus (CBPV) isolated from various geographical regions. Virus Research 144:334-338.

Botías, C., Martín-Hernández, R., Barrios, L., Meana, A., and Higes, M. 2013. Nosema spp. infection and its negative effects on honey bees (Apis mellifera iberiensis) at the colony level. Veterinary Research 44:25.

Bravo, J., Carbonella, V., Valdebenito, J.T., Figueroa, C., Valdovinos, C.E., Martín-Hernández, R., et al. 2014. Identification of Nosema ceranae in the Valparaíso District, Chile. Archivos de Medicina Veterinaria 46:487-491.

Chen, Y., Evans, J., and Feldlaufer, M. 2006. Horizontal and vertical transmission of viruses in the honey bee, Apis mellifera. Journal of Invertebrate Pathology 92:152-159.

Chen, Y., Evans, J.D., Smith, I.B., and Pettis, J.S. 2008. Nosema ceranae is a long-present and wide-spread microsporidian infection of the European honey bee (Apis mellifera) in the United States. Journal of Invertebrate Pathology 97:186-188.

Chen, Y-P., and Siede, R. 2007. Honey bee viruses. Advances in Virus Research 70:33-80.

Dainat, B., Evans, J.D., Chen, Y.P., Gauthier, L., and Neumann, P. 2012. Dead or alive: deformed wing virus and Varroa destructor reduce the life span of winter honeybees. Applied and Environmental Microbiology 78:981-987.

De Miranda, J.R., Baley, L., Ball, B.V., Blanchard, P., Budge, G., Chejanovsky, N., et al. 2013. Standard methods for virus research in Apis mellifera. Journal of Apicultural Research 52:1-55.

De Miranda, J.R., Cordoni, G., and Budge, G. 2010. The acute bee paralysis virus-Kashmir bee virus-Israeli acute paralysis virus complex. Journal of Invertebrate Pathology 103:30-47.

Delaplane, K.S., and Mayer, D.F. 2004. Crop pollination by bees. University Press, Cambridge, UK.

Doublet, V., Labarussias, M., de Miranda, J.R., Moritz, R.F.A., and Paxton, R.J. 2015. Bees under stress: sublethal doses of a neonicotinoid pesticide and pathogens interact to elevate honey bee mortality across the life cycle. Environmental Microbiology 17:969-983.

Evans, J.D., and Schwarz, R.S. 2011. Bees brought to their knees: microbes affecting honey bee health. Trends in Microbiology 19:614-620.

Fries, I. 2010. Nosema ceranae in European honey bees (Apis mellifera). Journal of Invertebrate Pathology 103:73-79. 
Gisder, S., Hedtke, K., Möckel, N., Frielitz, M.-C., Linde, A., and Genersch, E. 2010. Fiveyear cohort study of Nosema spp. in Germany: Does climate shape virulence and assertiveness of Nosema ceranae? Applied and Environmental Microbiology 76:3032-3038

Higes, M., Martín, R., and Meana, A. 2006. Nosema ceranae, a new microsporidian parasite in honeybees in Europe. Journal of Invertebrate Pathology 92:93-95.

Higes, M., Martín-Hernández, R., Botías, C., Bailón, E.G., González-Porto, A.V., Barrios, L., et al. 2008. How natural infection by Nosema ceranae causes honeybee colony collapse. Environmental Microbiology 10:2659-2669.

Highfield, A.C., El Nagar, A., Mackinder, L.C., Noel, L.M., Hall, M.J., Martin, S.J., et al. 2009. Deformed wing virus implicated in overwintering honeybee colony losses. Applied and Environmental Microbiology 775:7212-7220.

Hinojosa A., y González, D. 2004. Prevalencia de parásitos en Apis mellifera en colmenares del secano costero e interior de la VI Región, Chile. Parasitología Latinoamericana 59:137-141.

Huang, W.F., and Solter, L.F. 2013. Comparative development and tissue tropism of Nosema apis and Nosema ceranae. Journal of Invertebrate Pathology 113:35-51.

Invernizzi, C., Abud, C., Tomasco, I.H., Harriet, J., Ramallo, G., Campá, J., et al. 2009. Presence of Nosema ceranae in honeybees (Apis mellifera) in Uruguay. Journal of Invertebrate Pathology 101:150-153.

Johnson, R.M., Evans, J.D., Robinson, G.E., and Berenbaum, M.R. 2009. Changes in transcript abundance relating to colony collapse disorder in honey bees (Apis mellifera). Procedures of the National Academy of Sciences of United States of America 106:14790-14795.

Klee, J., Besana, A.M., Genersch, E., Gisder, S., Nanetti, A., Tam, D.Q., et al. 2007. Widespread dispersal of the microsporidian Nosema ceranae, an emergent pathogen of the western honey bee, Apis mellifera. Journal of Invertebrate Pathology 96:1-10.

Kukielka, D., Esperon, F., Higes, M., and Sanchez-Vizcaino, J.M. 2008. A sensitive one step real-time RT-PCR method for detection of deformed wing virus and black queen cell virus in honeybee Apis mellifera. Journal of Virology Methods 147:275-281.

Kukielka, D., and Sanchez-Vizcaino, J.M. 2009. One-step realtime quantitative PCR assays for the detection and field study of Sacbrood honeybee and Acute bee paralysis viruses. Journal of Virology Methods 161:240-246.

Maggi, M., Antúnez, K., Invernizzi, C., Aldea, P., Vargas, M., et al. 2016. Honeybee health in South America. Apidologie 47:835-854.

Martín-Hernández, R., Botías, C., Bailón, E.G., MartínezSalvador, A., Prieto, L., Meana, A., et al. 2012. Microsporidia infecting Apis mellifera: coexistence or competition. Is Nosema ceranae replacing Nosema apis? Environmental Microbiology 14:2127-2138

Maslov, D.A., Votypka, J., Yurchenko, V., and Lukes, J. 2013. Diversity and phylogeny of insect trypanosomatids: all that is hidden shall be revealed. Trends Parasitology 29:43-52.

McMenamin, A.J., and Genersch, E. 2015. Honey bee colony losses and associated viruses. Current Opinion in Insect Science 8:121-129.

Milbrath, M.O., Van Tran, T., Huang, W.F., Solter, L.F., Tarpy, D.R., Lawrence, F., et al. 2015. Comparative virulence and competition between Nosema apis and Nosema ceranae in honey bees (Apis mellifera). Journal of Invertebrate Pathology 125:9-15.
Paxton, R.J., Klee, J., Korpela, S., and Fries, I. 2007. Nosema ceranae has infected Apis mellifera in Europe since at least 1998 and may be more virulent than Nosema apis. Apidologie 38:558-565.

Ravoet, J., Maharramov, J., Meeus, I., De Smet, L., Wenseleers, T., Smagghe, G., et al. 2013. Comprehensive bee pathogen screening in Belgium reveals Crithidia mellificae as a new contributory factor to winter mortality. PLoS ONE 8:e72443.

Rodríguez, M., Vargas, M., Antúnez, K., Gerding, M., OvídioCastro, F., and Zapata, N. 2014. Prevalence and phylogenetic analysis of honey bee viruses in the Biobío Region of Chile and their association with other honey bee pathogens. Chilean Journal of Agricultural Research 74:170-177.

Runckel, C., Flenniken, M.L., Engel, J.C., Ruby, J.G., Ganem, D., et al. 2011 Temporal analysis of the honey bee microbiome reveals four novel viruses and seasonal prevalence of known viruses, Nosema, and Crithidia. PLoS ONE 6:20656. doi:10.1371/journal.pone.0020656.

SAG. 2010. Informe de caso de Nosema ceranae en la Región del Biobío, octubre de 2009. Servicio Agrícola y Ganadero (SAG), Santiago, Chile.

Schwarz, R.S., Bauchan, G., Murphy, C., Ravoet, J., de Graaf, D.C., and Evans, J.D. 2015. Characterization of two species of Trypanosomatidae from the honey bee Apis mellifera: Crithidia mellificae Langridge and McGhee, 1967 and Lotmaria passim n. gen., n. sp. Journal of Eukaryotic Microbiology 62:567-583.

Schwarz, R.S., and Evans, J.D. 2013. Single and mixed-species trypanosome and microsporidia infections elicit distinct, ephemeral cellular and humoral immune responses in honey bees. Developmental and Comparative Immunology 40:300-310.

Sguazza, G.H., Reynaldi, F.J., Galosi, C.M., and Pecoraro, M.R. 2013. Simultaneous detection of bee viruses by multiplex PCR. Journal of Virological Methods 194:102-106.

Teixeira, E.W., dos Santos, L.G., Sattler, A., Message, D., Alves, M., et al. 2013. Nosema ceranae has been present in Brazil for more than three decades infecting Africanized honey bees. Journal of Invertebrate Pathology 114:250-254.

Valdés, P. 2014. Apicultura de precisión. Reporte $N^{\circ} 2$. p. 1-7. Oficina de Estudios y Políticas Agrarias (ODEPA), Santiago, Chile.

Velis, H., Silva, P., y Núñez, M. 2009. Producción apícola: informe anual 2008. 39 p. Instituto Nacional de Estadísticas (INE), Santiago, Chile.

Yang, X., and Cox-Foster, D.L. 2005. Impact of an ectoparasite on the immunity and pathology of an invertebrate: Evidence for host immunosuppression and viral amplification. Procedures of the National Academy of Sciences of the United States of America 102:7470-7475.

Zhang, X., He, S.Y., Evans, J.D., Pettis, J.S., Yin, G.F., and Chen, Y.P. 2012. New evidence that deformed wing virus and black queen cell virus are multi-host pathogens. Journal of Invertebrate Pathology 109:156-159.

Zheng, H.Q., Gong, H.R., Huang, S.K., Sohr, A., Hu, F.L., and Chen, Y.P. 2015. Evidence of the synergistic interaction of honey bee pathogens Nosema ceranae and deformed wing virus. Veterinary Microbiology 177:1-6. 